\title{
Modified biomass of Phanerochaete chrysosporium immobilized on luffa sponge for biosorption of hexavalent chromium
}

\author{
D. K. Verma $\cdot$ S. H. Hasan . \\ D. Ranjan $\cdot$ R. M. Banik
}

Received: 8 November 2012/Revised: 4 April 2013/Accepted: 26 May 2013/Published online: 2 July 2013

(C) Islamic Azad University (IAU) 2013

\begin{abstract}
Phanerochaete chrysosporium, a white rot basidiomycete, was immobilized over Luffa cylindrica sponge discs, treated with $0.1 \mathrm{~N} \mathrm{HCl}$ and its potentiality for the removal of hexavalent chromium $[\mathrm{Cr}(\mathrm{VI})]$ from water was investigated in both batch and in up-flow fixed-bed bioreactor. The acid treatment of biomass increased the uptake capacity and percentage removal of $\mathrm{Cr}(\mathrm{VI})$ from 33.5 to $46.5 \mathrm{mg} \mathrm{g}^{-1}$ and 67 to $92 \%$, respectively. Maximum uptake of $\mathrm{Cr}(\mathrm{VI})$ was achieved at $\mathrm{pH} 2$, temperature $40{ }^{\circ} \mathrm{C}$ after $100 \mathrm{~min}$ of contact time. The $\mathrm{Cr}(\mathrm{VI})$ sorption on the biomass was better explained by Langmuir isotherm. Thermodynamic studies indicated that the process was spontaneous and endothermic. Sorption kinetic study showed that pseudo-second-order model best correlates the $\mathrm{Cr}(\mathrm{VI})$ sorption on the biomass as compare to pseudo-firstorder kinetic model. The performance of fixed-bed bioreactor was evaluated at different bed heights $(5,15$ and $25 \mathrm{~cm})$ and flow rates $\left(1.66,4.98\right.$ and $8.33 \mathrm{~mL} \mathrm{~min}^{-1}$ ) by using bed depth service time model. Response surface methodology statistical method was applied for optimizing
\end{abstract}

Electronic supplementary material The online version of this article (doi:10.1007/s13762-013-0345-6) contains supplementary material, which is available to authorized users.

\section{K. Verma · R. M. Banik $(\bowtie)$}

School of Biochemical Engineering, Indian Institute

of Technology (Banaras Hindu University),

Varanasi 221005, U.P., India

e-mail:rmbanik@gmail.com

S. H. Hasan · D. Ranjan

Water Pollution Research Laboratory, Department of Applied Chemistry, Indian Institute of Technology (Banaras Hindu University), Varanasi 221005, U.P., India the process parameters. FTIR analysis showed that amino groups were mainly involved in adsorption of $\mathrm{Cr}(\mathrm{VI})$.

Keywords Immobilized Phanerochaete chrysosporium . Chromium biosorption - Up-flow fixed-bed bioreactor . Response surface methodology

\section{Introduction}

Heavy metals are among the most hazardous pollutants in source and treated water and are becoming a multiple problem causing agents. Chromium is the metal contaminant which exists as oxyanions in aqueous system like arsenic and selenium. Chromium is found in both trivalent and hexavalent form. Trivalent form of chromium is relatively innocuous, whereas hexavalent chromium [Cr(VI)] is toxic, carcinogenic, mutagenic and teratogenic in nature (Gupta et al. 2011a, b, c; Bai and Abraham 2002) Many industries like leather tanning, electroplating, dyeing, metal processing, paint, textile, steel fabrication and canning industry are the source of discharge containing high amount of chromium. The concentration of $\mathrm{Cr}(\mathrm{VI})$ in industrial effluent water ranges from 0.5 to $270.0 \mathrm{mg} \mathrm{L}^{-1}$. However, United States Environmental Protection Agency (1990) has fixed the permissible limit of $\mathrm{Cr}(\mathrm{VI})$ for industrial discharge up to $0.1 \mathrm{mg} \mathrm{L}^{-1}$ for surface water and $0.05 \mathrm{mg} \mathrm{L}^{-1}$ in potable water (Demirbas et al. 2004). Therefore, the removal of $\mathrm{Cr}(\mathrm{VI})$ from industrial effluents is essential before discharging them into water bodies or on to land. Various treatment processes are available for removal of $\mathrm{Cr}(\mathrm{VI})$, some of them are in frequent use such as reduction and precipitation, lime coagulation, ion exchange, solvent extraction and reverse osmosis. Treatment cost, operational complexity, skill requirement and 
disposal protocol are the key factors which decides the suitability and utility of the treatment method and should be considered before selecting a treatment method. In the context of above factors, adsorption is a promising approach for the remediation of different contaminant such as dyes (Gupta et al. 2011c, Mittal et al. 2010a, b, c), fluorinated compounds (Gupta et al. 2007), phenolic contaminants (Mittal et al. 2009a, b) and more importantly hazardous metals (Gupta et al. 2001, 2011a, b; Fourest and Volesky 1997). Activated carbon-based adsorption systems are being widely used in industries (Gupta et al. 1997). Biosorption by inexpensive biomaterials can be an excellent cost effective, eco-friendly alternative for the removal of metal ions and other pollutants from water (Gupta et al. 2010; Mittal et al. 2010a, $b, c)$.

Fungal biomasses have good capability to remove toxic heavy metals and other organic pollutants from aqueous solution (Perez et al. 1997). The biomass system becomes better in mechanical stability and easy to handle after immobilization. The ideal immobilization matrix should be highly porous, mechanically strong and sustainable at various $\mathrm{pH}$ and salt concentrations. The luffa sponge is a plant derived, inexpensive and easily available natural material which can be used as an immobilization matrix. The luffa sponge is an open interwoven network of cellulosic fibres. It provides support to fungal mycelium and allows rapid growth over it.

Phanerochaete chrysosporium is a known biosorbent tested for removal of various heavy metals from water chlorinated compounds and was found to be efficient in removing the contaminants from water (Reddy et al. 1998). In contrast, the negative charge of fungal cell wall reduces the efficiency of fungal biomass for the removal of metals which exist in oxyanionic form, such as arsenic, selenium and chromium. In the light of above fact, the alteration in the surface and surface charge through chemical treatment may be an alternative to enhance the affinity of biomass for metal oxyanions (Murugesan et al. 2006). In the present study, chemically treated immobilized biomass of $P$. chrysosporium on luffa sponge has been selected for the sorption of hexavalent chromium.

The objective of the study is to enhance $\mathrm{Cr}(\mathrm{VI})$ biosorption capacity of fungal biomass through chemical treatment and evaluation of its potentiality in batch and continuous adsorption process along with statistical optimization using response surface methodology (RSM). Response surface is the graphical representation of the multivariate regression equations, which represents the relationships between explanatory variables and response variables. Amongst the various designs available in RSM, the full-factorial central composite design (CCD) is the most commonly used (Tan et al. 2008).

\section{Materials and methods}

Micro-organism, culture medium, immobilization and pre-treatment

Phanerochate crysosporium MTCC 787, a member of class basidiomycetes commonly known as white rot fungus, was maintained by subculturing on slants containing malt extract agar (MEA) media incubated at $25^{\circ} \mathrm{C}$ and stored at $4{ }^{\circ} \mathrm{C}$. Constituents of the MEA were $\left(\mathrm{g} \mathrm{L}^{-1}\right)$ as follows: malt extract 20.0; glucose 20.0; peptone 1.0 and agar 20.0 (pH 5.5). Growth and immobilization of fungus over luffa sponge were carried out in a synthetic media containing $\left(\mathrm{g} \mathrm{L}^{-1}\right)$ as follows: D-glucose $10.0 ; \mathrm{KH}_{2} \mathrm{PO}_{4}$ 2.0; $\mathrm{MgSO}_{4} \cdot 7 \mathrm{H}_{2} \mathrm{O} 0.5 ; \mathrm{NH}_{4} \mathrm{Cl} 0.1 ; \mathrm{CaCl}_{2} \cdot 2 \mathrm{H}_{2} \mathrm{O} 0.1$; thiamine 0.001 and $\mathrm{pH} 4.5$ (Iqbal et al. 2005). Immobilization of $P$. chrysosporium on luffa sponge discs was done using method described by M. Iqbal (Iqbal et al. 2005).

$0.1 \mathrm{~N} \mathrm{H}_{2} \mathrm{SO}_{4}, 0.1 \mathrm{~N} \mathrm{HCl}, 0.1 \mathrm{~N} \mathrm{NaOH}, 0.1 \mathrm{~N} \mathrm{NH}_{4} \mathrm{OH}$, formaldehyde $(10 \% \mathrm{v} / \mathrm{v}), \mathrm{FeCl}_{3}\left(15 \mathrm{mg} \mathrm{L}^{-1}\right)$ and polyethylenimine (PEI) $(1 \% \mathrm{w} / \mathrm{v})$ were individually used for the chemical treatment of biomass. In the experiment, untreated immobilized biomass (IFB) was used as a control, and other process parameters were fixed at $100 \mathrm{mg} \mathrm{L}^{-1}$ initial $\mathrm{Cr}(\mathrm{VI})$ concentration, $2.0 \mathrm{~g} \mathrm{~L}^{-1}$ biomass dose, $\mathrm{pH} 2.0,12 \mathrm{~h}$ of contact time and agitation speed $100 \mathrm{rpm}$. The resulted modified biomass was then separated from the solution and washed with deionised water before adsorption experiments.

\section{Batch biosorption studies in shake flasks}

All the standards and reagents were prepared in deionised double-distilled water using all analytical grade chemicals. Stock solution of $\mathrm{Cr}(\mathrm{VI})$ was prepared by dissolving the corresponding weight of potassium dichromate $\left(\mathrm{K}_{2} \mathrm{Cr}_{2} \mathrm{O}_{7}\right)$ to obtain a solution of $1,000 \mathrm{mg} \mathrm{L}^{-1}$. Working solution of desired concentrations was obtained after further diluting the stock solution. Batch experiments were conducted using $100 \mathrm{~mL}$ of working solution in 250-mL Erlenmeyer flasks and agitating at $100 \mathrm{rpm}$ with varying biomass dose, metal concentration, $\mathrm{pH}$ and temperature. Samples were taken out at regular time interval for the analysis of residual chromium in the solution. All the experiments were performed in triplicates, and the average value was taken. 
Biosorption studies in up-flow fixed-bed bioreactor

Continuous mode biosorption experiments were conducted using bioreactor that is made up of borosilicate glass having internal diameter $2 \mathrm{~cm}$ and length $30 \mathrm{~cm}$. Treated immobilized biomass discs (CIFB) were packed between two supporting layers of $1 \mathrm{~cm}$ of glass wool in bioreactor to attend different bed heights. Metal ion solution having the desired initial metal ion concentration was pumped in an up-flow mode through the bioreactor at the desired flow rate by a peristaltic pump (Miclins PP-10). Samples were collected at regular time intervals, and $\mathrm{Cr}(\mathrm{VI})$ concentration in the samples was analysed. After the exhaustion of bed, $100 \mathrm{~mL}$ of deionized double-distilled water was passed through bioreactor in an upward direction to wash out the bioreactor. Desorption was carried out by passing the eluting agent $(10 \% \mathrm{NaOH})$ through the bioreactor bed in an upward direction at a flow rate of $1.66 \mathrm{~mL} \mathrm{~min}^{-1}$. The effluent metal solution was collected and analysed for elution efficiency and $\mathrm{Cr}(\mathrm{VI})$ content.

Analysis of $\mathrm{Cr}(\mathrm{VI})$ and $\mathrm{Cr}(\mathrm{III})$ in aqueous solution

Working solution initially contains only $\mathrm{Cr}(\mathrm{VI})$ species, but during the adsorption process, $\mathrm{Cr}$ (III) also appears in the solution due to the reduction of $\mathrm{Cr}(\mathrm{VI})$ through biomass. The determination of total chromium was done by atomic absorption spectrophotometer (AAS) (Shimadzu AA-6300) with hollow cathode lamp and using $12 \mathrm{~mA}$ lamp current, $0.7 \mathrm{~nm}$ slit width, light source set at $357.9 \mathrm{~nm}$ wavelength and deuterium lamp for background correction. The instrument was calibrated from 0.03 to $10.0 \mathrm{mg} \mathrm{L}^{-1}$ $\mathrm{Cr}(\mathrm{VI})$ using $\mathrm{Cr}\left(\mathrm{NO}_{3}\right)_{3}$ in $0.5 \mathrm{~mol} \mathrm{~L}{ }^{-1} \mathrm{HNO}_{3}$ (Merck) standard solution samples. For determination of $\mathrm{Cr}(\mathrm{VI})$, the samples were again analysed by colorimetric method after complexation with 1-5 diphenylcabazide, and optical density was measured at $540 \mathrm{~nm}$ by UV spectrophotometer (Shimadzu UV mini 1240) (Yang and Chen 2008). The concentration of $\mathrm{Cr}$ (III) was then obtained by subtracting the concentration of $\mathrm{Cr}(\mathrm{VI})$ from the total chromium content of the corresponding sample.

Theory and equations

Equations used in present study for the calculations of different parameters along with brief theory are tabulated in Table 1.

Bed depth service time (BDST) model for evaluation of bioreactor performance

BDST model was used for predicting the relationship between bed height $(Z)$ and service time $(t)$ in terms of process concentrations and adsorption parameters, which is required for evaluating the performance of a fixed-bed bioreactor and designing the continuous bioreactor for the given process. The original BDST model was proposed by (Bohart and Adams 1920) and represented by the following Eq. (1):

$\ln \left(\frac{C_{o}}{C_{b}}-1\right)=\ln \left(\exp \left(\frac{k_{a} N_{o} Z}{u}\right)-1\right)-k_{a} C_{o} t$

Hutchins, correlated bed height $(Z)$ and service time $(t)$ in a linier manner as per given Eq. (2) (Hutchins 1973):

$t=\frac{N_{o} Z}{C_{o} u}-\frac{1}{k_{a} C_{o}} \ln \left(\frac{C_{o}}{C_{b}}-1\right)$

\section{Results and discussion}

Immobilization of $P$. chrysosporium on luffa sponge

The fungus was grown in luffa sponge-free media and in the media containing luffa sponge discs. Natural fibrous network of luffa sponge discs provided a supporting matrix for growth of the organism which lead to $20.4 \%$ higher growth as compare to the growth of organism in the medium without luffa sponge. The growth of the fungus on luffa sponge disc reaches to maximum on 8th day of incubation. After full growth of micro-organism, the discs were taken out and oven dried at $70{ }^{\circ} \mathrm{C}$ overnight. The average yield of dry weight of immobilized biomass was $392 \pm 16 \mathrm{mg} \mathrm{g}^{-1}$ of dry luffa sponge, and the amount of biomass immobilized on the fibrous luffa sponge disc was about threefold higher than the same organism immobilized within Ca-alginate beads (Kacar et al. 2002; Iqbal and Edyvean 2005).

\section{Effect of immobilization on biosorption of $\mathrm{Cr}(\mathrm{VI})$}

Removal of $\mathrm{Cr}(\mathrm{VI})$ from water was studied using the immobilized biomass and pre-grown-free fungal pallets. Immobilized biomass shows $4.26 \mathrm{mg} \mathrm{g}^{-1}$ increase in uptake capacity as compared to free fungal biomass. The Immobilized biomass showed higher uptake capacity because after immobilization, fungal biomass becomes less compact as compare to free biomass pallets. Decrease in compactness increases the accessibility of fungal surface for the adsorption of metal ions; thus, the effective surface area for adsorption increases that leads to increase in the uptake capacity of biomass.

\section{Effect of pre-treatment on biosorption of $\mathrm{Cr}(\mathrm{VI})$}

Treatment agent screening experiments were performed, and uptake capacities of CIFBs with the tested chemicals were found as follows: $\mathrm{NaOH} 14.5 \mathrm{mg} \mathrm{g}^{-1}, \mathrm{NH}_{4} \mathrm{OH}$ $23.8 \mathrm{mg} \mathrm{g}^{-1}$, formaldehyde (HCHO) $19.5 \mathrm{mg} \mathrm{g}^{-1}, \mathrm{H}_{2} \mathrm{SO}_{4}$ 
Table 1 List of equations along with brief theory for the calculations of different parameters

\begin{tabular}{|c|c|}
\hline Parameters and brief theory & Equations \\
\hline Uptake capacity or sorption capacity metal adsorbed per unit mass of the adsorbent & $\begin{array}{l}q_{\mathrm{t}}=\frac{\left(C_{\mathrm{i}}-C_{\mathrm{t}}\right) \times V}{W} \\
\% \text { Removal }=\frac{\left(C_{i}-C_{\mathrm{t}}\right)}{C_{\mathrm{i}}} \times 100\end{array}$ \\
\hline $\begin{array}{l}\text { Langmuir sorption isotherm adsorption takes place on a homogeneous surface in a monolayer pattern without } \\
\text { interaction between adsorbed neighbour molecules (Mittal et al. 2009a, b). For good sorbents, high values } \\
\text { of } Q^{\circ} \text { and low values of } b \text { are desirable (Langmuir 1918) }\end{array}$ & $C_{\mathrm{e}} / q_{e}=1 / Q^{\mathrm{o}} b+C_{\mathrm{e}} / Q^{\mathrm{o}}$ \\
\hline $\begin{array}{l}\text { Freundlich sorption isotherm assumption is that the binding sites with stronger affinity are occupied first and } \\
\text { binding strength of later adsorbed solute molecules decreases with increase in extent of site occupation } \\
\text { (Freundlich 1907) }\end{array}$ & $\log q_{\mathrm{e}}=\log K_{\mathrm{F}}+1 / n \log C_{\mathrm{e}}$ \\
\hline $\begin{array}{l}\text { Thermodynamic studies brief idea about thermodynamic parameters }\left(\Delta G, \Delta H, \Delta S \text { and } K_{c} \text { ) is required to }\right. \\
\text { understand the nature and changes of the sorption process reaction (Nouri et al. 2007). Parameters can be } \\
\text { calculated with the help of Van't Hoff plot (ln Kc vs. 1/T) and given equations (Liu and Liu 2008) }\end{array}$ & $\begin{array}{l}\Delta G=-\mathrm{RT} \ln K \mathrm{c} \\
K_{\mathrm{c}}=C_{\mathrm{Ae}} / C_{\mathrm{e}} \\
\ln K_{\mathrm{c}}=-\Delta H / \mathrm{RT}+\Delta S / R\end{array}$ \\
\hline $\begin{array}{l}\text { Sorption kinetics sorption kinetics study is necessary in order to design the sorption systems and to predict } \\
\text { solute removal rate, which governs the residence time (Ho 2006). Several sorption kinetic models have } \\
\text { been proposed and among these, two models, namely pseudo-first-order and pseudo-second-order model } \\
\text { equations, are in widely use to describe sorption process (Erdem and Ozverdi 2006; Kiran et al. 2006) }\end{array}$ & $\begin{array}{l}\text { Pseudo-first-order model } \\
\text { (Pokhrel and Viraraghavan } \\
\text { 2007; Singh et al. 2005) } \\
\log \left(q_{\mathrm{e}}-q_{\mathrm{t}}\right)=\log \left(q_{\mathrm{e}}\right)-\frac{k_{\mathrm{s}}}{2.303} t \\
\text { Pseudo-second-order model (Ho } \\
\text { and McKay 1999): } \\
\frac{t}{q_{\mathrm{t}}}=\frac{1}{k_{2}^{\prime} q_{\mathrm{e}}^{2}}+\frac{1}{q_{\mathrm{e}}} t \\
\text { initial sorption rate }(h): h=k_{2}^{\prime} q_{\mathrm{e}}^{2}\end{array}$ \\
\hline \multicolumn{2}{|l|}{ Calculation of fixed-bed bioreactor parameters (Vijayaraghavan et al. 2005) } \\
\hline $\begin{array}{l}\text { (a) Breakthrough curve }\left(C_{t} / C_{o} \text { vs. time }\right) \text { helps to analyse the dynamic sorbate removal in up-flow fixed-bed } \\
\text { bioreactor. Effluent volume }\left(\mathrm{V}_{\mathrm{eff}}\right) \text { treated at any time }(\mathrm{t}) \text { is represented by given equation. Effluent volume } \\
\text { treated up to breakthrough time }\left(t_{b}\right) \text { and bed exhaustion time }\left(t_{e}\right) \text { is denoted as } V_{b} \text { and } V_{\mathrm{e}} \text {, respectively }\end{array}$ & $V_{\mathrm{eff}}=Q \times t$ \\
\hline b) Total amount of metal ion fed to the bioreactor $(X)$ & $X=\frac{C_{0} Q t_{\mathrm{e}}}{1,000}$ \\
\hline $\begin{array}{l}\text { (c) Uptake capacity of the biomass in bioreactor ( } q_{\mathrm{tot}} \text {, calculated from the area above the breakthrough } \\
\text { curve) }\end{array}$ & $q=\frac{q_{\mathrm{tot}}}{M}$ \\
\hline (d) Elution efficiency $(E)$ [metal mass desorbed $\left(m_{\mathrm{d}}\right)$ was calculated from the elution curve $\left(C_{t}\right.$ vs. $\left.t\right)$ ]. & $E(\%)=m_{\mathrm{d}} / q$ tot $\times 100$ \\
\hline $\begin{array}{l}\text { (e) Empty bed contact time ( } E B C T \text { ) time required filling the empty bioreactor with the liquid at constant } \\
\text { flow rate. It affects the shape of the breakthrough curve. }\end{array}$ & $\mathrm{EBCT}=\frac{V_{\mathrm{c}}}{Q}=\frac{A_{\mathrm{c}} Z}{Q}$ \\
\hline (f) Sorbent usage rate $\left(U_{r}\right)$ weight of sorbent saturated per litre of solution treated. & $U_{\mathrm{r}}=\frac{M}{V_{\mathrm{b}}}=\frac{V_{\mathrm{c}} \rho}{V_{\mathrm{c}} N_{\mathrm{b}}}=\frac{\rho}{N_{\mathrm{b}}}$ \\
\hline $\begin{array}{l}\text { (g) Critical bed height }\left(Z_{\mathrm{o}}\right) \text { theoretical height bed required to ensure that the outlet solute concentration } \\
\text { does not exceed the breakthrough concentration } C_{\mathrm{b}} \text {. }\end{array}$ & $Z_{\mathrm{o}}=\frac{u}{k_{\mathrm{a}} N_{\mathrm{o}}} \ln \left(\frac{C_{\mathrm{o}}}{C_{\mathrm{b}}}-1\right)$ \\
\hline
\end{tabular}

$37.6 \mathrm{mg} \mathrm{g}^{-1}$, polyethylemine (PEI) $39.6 \mathrm{mg} \mathrm{g}^{-1}, \mathrm{FeCl}_{3}$ $43.6 \mathrm{mg} \mathrm{g}^{-1}$ and for $\mathrm{HCl} 46.5 \mathrm{mg} \mathrm{g}^{-1}$, respectively. After comparing uptake capacities of pre-treated biomasses, $0.1 \mathrm{~N} \mathrm{HCl}$ was selected for the pre-treatment of biomass in further experiments.

\section{Effect of $\mathrm{pH}$ on reduction and biosorption of $\mathrm{Cr}(\mathrm{VI})$}

The effect of $\mathrm{pH}$ on the biosorption of $\mathrm{Cr}(\mathrm{VI})$ was investigated by performing the experiments at $40{ }^{\circ} \mathrm{C}$ temperature, $100 \mathrm{mg} \mathrm{L}^{-1} \mathrm{Cr}(\mathrm{VI})$ initial metal concentration, biomass dose $2 \mathrm{~g} \mathrm{~L}^{-1}$ and varying $\mathrm{pH}$ from 1.0 to 12 . The maximum uptake capacities of FFB, IFB and CIFB were found to be $29.25,33.5$ and $46.5 \mathrm{mg} \mathrm{g}^{-1}$, respectively, at pH 2.0 (Fig. 1a). Cr(VI) in the solution exists mainly in three ionic states, $\mathrm{HCrO}_{4}{ }^{-}, \mathrm{Cr}_{2} \mathrm{O}_{7}{ }^{2-}$ and $\mathrm{CrO}_{4}{ }^{2-}$ at acidic $\mathrm{pH}$. Lowering of $\mathrm{pH}$, results in the protonation of surface groups to a higher extent leading to greater electrostatic attraction between the chromium oxianions and positively charged surface groups. Consequently, the metal uptake increases with decrease in the $\mathrm{pH}$ of the solution. While at higher $\mathrm{pH}$, the uptake of $\mathrm{Cr}(\mathrm{VI})$ lowers down due to increase in the number competitive hydroxyl anions along with unfavourable negative charge over the fungal cell wall. The $\mathrm{Cr}(\mathrm{VI})$ remediation takes place by reduction of $\mathrm{Cr}$ (VI) into $\mathrm{Cr}$ (III) followed by its adsorption over the biomass surface through complexation with the surface groups (Hasan et al. 2008). Moreover, results obtained as represented in Fig. 2a, b clearly illustrates the effect of $\mathrm{pH}$ on the $\mathrm{Cr}(\mathrm{VI})$ reduction and its biosorption for both untreated and treated biomass. At experimental $\mathrm{pH}(\mathrm{pH}$ 2.0), $\mathrm{HCrO}_{4}{ }^{-}$predominates (Kobya 2004) and the reduction of $\mathrm{HCrO}_{4}^{-}$is also clear from aqueous chemistry as represented by the given redox reaction: 
$\mathrm{HCrO}_{4}^{-}+7 \mathrm{H}^{+}+3 \mathrm{e}^{-} \leftrightarrow \mathrm{Cr}^{3+}+4 \mathrm{H}_{2} \mathrm{O}$

With the help of the Nernst equation, the redox potential of $\mathrm{HCrO}_{4}{ }^{-} / \mathrm{Cr}(\mathrm{III})$ can be calculated as follows:

$E=E^{\circ}+0.0197 \log \frac{\left[\mathrm{HCrO}^{4-}\right]}{\left[\mathrm{Cr}^{3+}\right]}-0.138 \mathrm{pH}$

As Eqs. 3 and 4 clearly indicate the involvement of both protons and electrons in the sorption process and strong effect of $\mathrm{pH}$ on the redox potential, respectively. The reason of favourable biosorption at lower $\mathrm{pH}$ might be associated with the protonation of surface functional groups, positive surface charge at low $\mathrm{pH}$ and increase in the redox potential at adsorption $\mathrm{pH}$.

However, hike in the uptake capacity after acid treatment may be due to the fact that acid treatment further improves the reducing capability of the biomass as evident from Fig. 2a, b, where Cr(III) species was present in the
Fig. 1 a Effect of $\mathrm{pH}$ on $\mathrm{Cr}(\mathrm{VI})$ sorption capacity of biomasses. Conditions: initial metal concentration $100 \mathrm{mg} \mathrm{L}^{-1}$; temperature $40^{\circ} \mathrm{C}$; biomass dose $2.0 \mathrm{~g} \mathrm{~L}^{-1}$ contact time $3 \mathrm{~h}$ at $100 \mathrm{rpm}$. b Effect of metal ion concentration on $\mathrm{Cr}(\mathrm{VI})$ sorption capacity and percentage removal. Conditions: $\mathrm{pH} 2.0$; temperature $40{ }^{\circ} \mathrm{C}$; contact time $3 \mathrm{~h}$ at $100 \mathrm{rpm}$. c Effect of biomass dose on $\mathrm{Cr}(\mathrm{VI})$ sorption capacity and percentage removal. Conditions: $\mathrm{pH} 2.0$; temperature $40{ }^{\circ} \mathrm{C}$; initial metal concentration $100 \mathrm{mg} \mathrm{L}^{-1}$ and contact time $3 \mathrm{~h}$ at $100 \mathrm{rpm}$. FFB-free fungal biomass, IFBimmobilized fungal biomass, CIFB - chemically treated immobilized fungal biomass
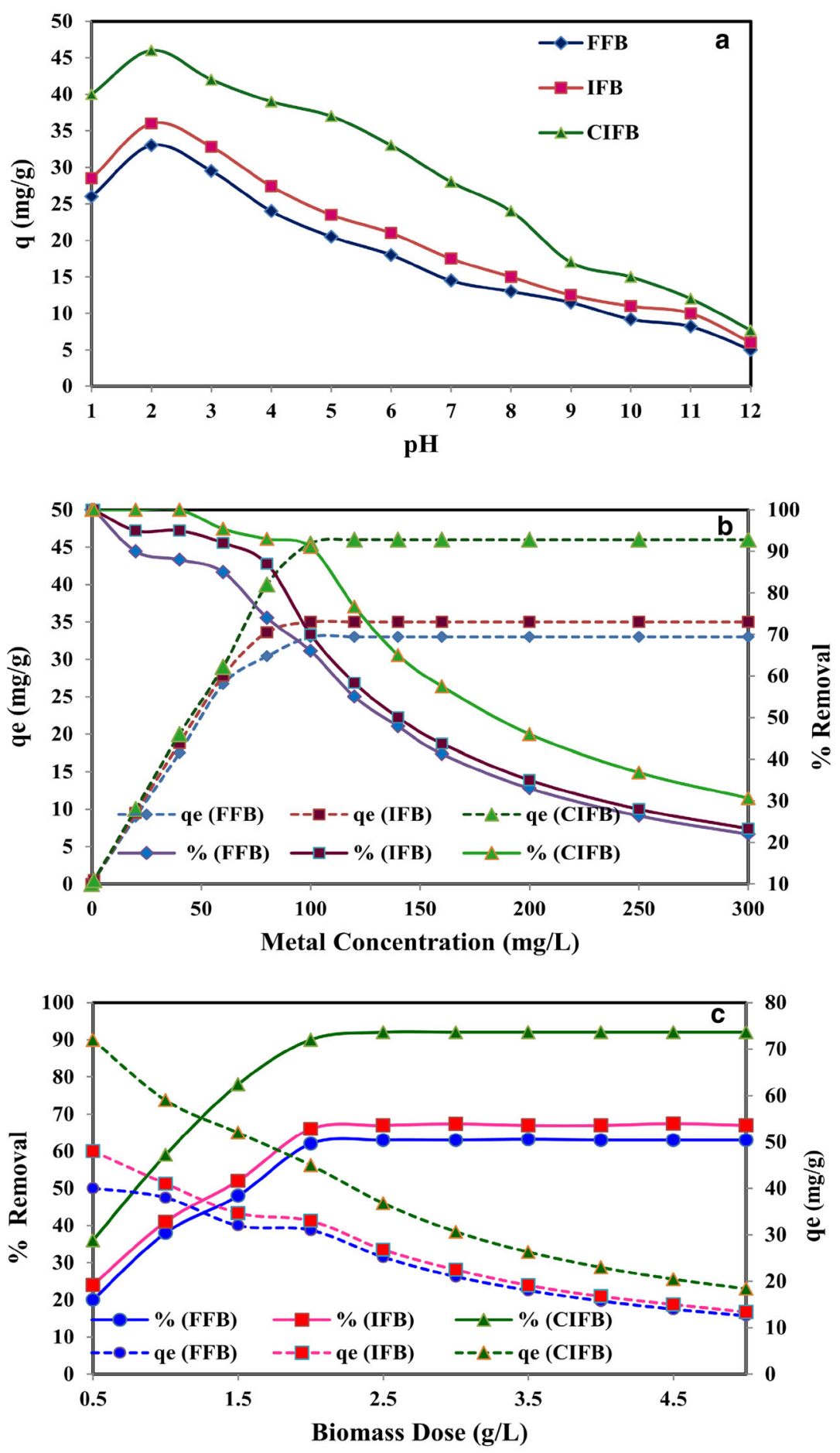

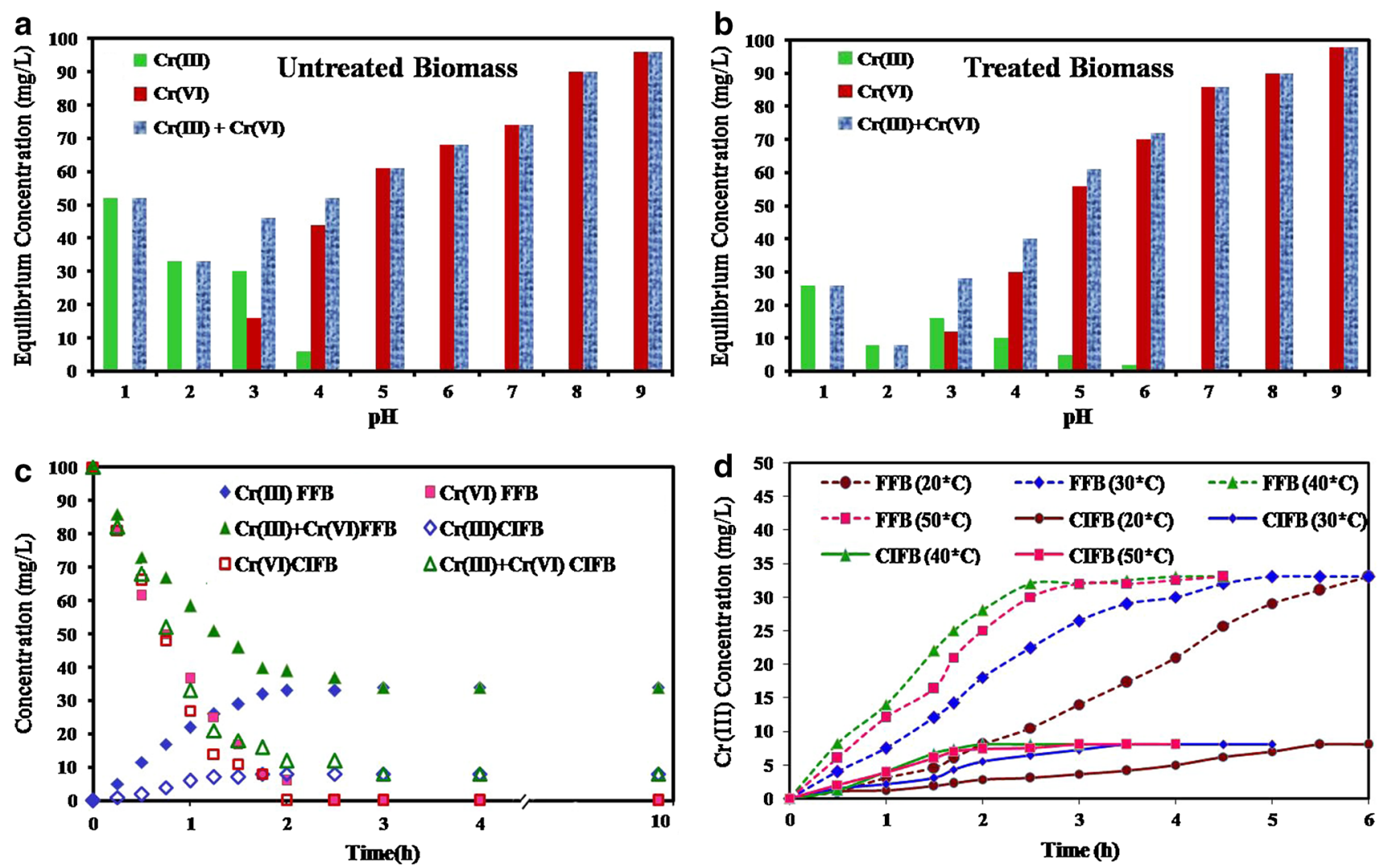

Fig. 2 a and b Distribution of chromium species [Cr(VI), $\mathrm{Cr}(\mathrm{III})$ and total chromium] in solution after adsorption. Conditions: initial metal concentration $100 \mathrm{mg} \mathrm{L}^{-1}$; temperature $40{ }^{\circ} \mathrm{C}$; biomass dose $2.0 \mathrm{~g} \mathrm{~L}^{-1}$ contact time $3 \mathrm{~h}$ at $100 \mathrm{rpm}$. c Distribution of chromium species in solution at different times. Conditions: initial metal concentration $100 \mathrm{mg} \mathrm{L}^{-1}$; temperature $40{ }^{\circ} \mathrm{C}$; biomass dose

$2.0 \mathrm{~g} \mathrm{~L}^{-1}$; pH 2.0 at $100 \mathrm{rpm}$. Solid symbols represent untreated free fungal biomass (FFB), and solid symbol represents chemically treated immobilized fungal biomass (CIFB). d Effect of temperature on chromium biosorption. Conditions: initial metal concentration $100 \mathrm{mg} \mathrm{L}^{-1}$; biomass dose $2.0 \mathrm{~g} \mathrm{~L}^{-1}$; pH 2.0 at $100 \mathrm{rpm}$. Dotted lines represent $\mathrm{FFB}$, and solid lines denote $\mathrm{CIFB}$

system up to the $\mathrm{pH} 6.0$ in case of treated biomass while $\mathrm{Cr}$ (III) was present only up to $\mathrm{pH} 4.0$ in case of untreated biomass. Furthermore, acid pre-treatment might expose more binding sites by cleanup the surface of biomass through replacing the already bound ionic species with the protons and sulphates over the biomass surface (Park et al. 2005). Bai and Abraham (2002) and Nair and Madhavan (1992) have also reported that acid treatment increases the number of surface groups due to the appearance of relatively pure amino sugars (D-glucosamines) which are more easily protonatated at biosorption $\mathrm{pH}$ (Bai and Abraham 2002; Nair and Madhavan 1992).

\section{Effect of contact time}

Effect of contact time was studied at an initial solution $\mathrm{pH}$ 2.0, initial metal ion concentration of $100 \mathrm{mg} \mathrm{L}^{-1}$, biomass dose $2.0 \mathrm{~g} \mathrm{~L}^{-1}$ and temperature $40{ }^{\circ} \mathrm{C}$ for FFB and CIFB to find out the time required for the establishment of equilibrium of adsorption process. Initially, $\mathrm{Cr}$ (III) species was absent, but due to reduction of the $\mathrm{Cr}(\mathrm{VI})$ species, it

appears into the system, and $\mathrm{Cr}$ (III) concentration gradually increases in the system until equilibrium get established. At biosorption $\mathrm{pH}$, the $\mathrm{Cr}(\mathrm{VI})$ concentration was decreased up to zero which indicates the complete reduction of hexavalent chromium into trivalent form at biosorption $\mathrm{pH}$. Total chromium content also decreases up to equilibrium (Fig. 2c). Initially, rapid adsorption takes place and equilibrium was achieved in near about $120 \mathrm{~min}$ in case of FFB, while equilibrium was achieved in about $100 \mathrm{~min}$ in case of CIFB. This indicates the faster rate of adsorption over acid-treated biomass as compare to biomass without any chemical pre-treatment.

Effect of initial metal ion concentration

The effect of metal ion concentration on the $\mathrm{Cr}(\mathrm{VI})$ uptake of biomass was investigated using initial metal ion concentration range from 1 to $300 \mathrm{mg} \mathrm{L}^{-1}$ at $\mathrm{pH} 2.0$, biomass dose $2.0 \mathrm{~g} \mathrm{~L}^{-1}$ and temperature $40{ }^{\circ} \mathrm{C}$. As indicated by Fig. 1b, initially uptake capacity of biomass increases with increase in metal ion concentration, but at high metal 
concentration, biomass becomes saturated and does not show further increase in adsorption capacity of biomass, while percentage removal decreases with increase in metal ion concentration. FFB gets saturated at lower metal ion concentration (at $70 \mathrm{mg} \mathrm{L}^{-1}$ ) as compared to CIFB which saturates at $100 \mathrm{mg} \mathrm{L}^{-1}$. The uptake capacity of biomass was found to be highest at initial metal ion concentration $100 \mathrm{mg} \mathrm{L}^{-1}$, pH 2.0 and temperature $40{ }^{\circ} \mathrm{C}$. Further increase in the metal ion concentration does not increase the uptake capacity of biomass.

\section{Effect of biomass dose}

The effect of biomass dose on the biosorption of $\mathrm{Cr}(\mathrm{VI})$ was investigated by performing the experiments at $\mathrm{pH}$ of 2.0, initial metal ion concentration $100 \mathrm{mg} \mathrm{L}^{-1}$, temperature $40{ }^{\circ} \mathrm{C}$ and varying biomass dose from 1 to $5 \mathrm{gm} \mathrm{L}^{-1}$. Results are represented in Fig. 1c. It was found that the uptake decreased with increase in biomass dose while percentage removal increases with increase in biomass dose. At high sorbent dose, the available solute is insufficient to completely cover the available exchangeable sites present over the biosorbent surface, which usually results the reduction in the uptake capacity of biosorbents while at high biomass dose, percentage removal increases due to excess availability of binding sites. In addition to this, further increased biosorbent dose also causes the interference between binding sites thus uptake capacity of biomass declines, also after some time, adsorption was governed by equilibrium and further increase in the biomass dose does not affect the adsorption and percentage chromium removal.

\section{Sorption isotherms}

Adsorption isotherms correlate the adsorbate concentration in aqueous phage with its concentration at adsorbateadsorbent interface (Mittal et al. 2010a, b, c). The study of isotherms was carried out by varying initial metal ion concentration from 100 to $250 \mathrm{mg} \mathrm{L}^{-1}$ for FFB, IFB and CIFB and keeping other parameters constant at $\mathrm{pH} 2.0$, biomass dose $2.0 \mathrm{~g} \mathrm{~L}^{-1}$ and temperature $40^{\circ} \mathrm{C}$. Figure $3 \mathrm{~b}$ represents Langmuir isotherms which better fits the current adsorption system as indicated by correlation coefficient, and values of isotherm constants of both Langmuir isotherms and Freundlich isotherms are presented in Table 2. The supportive Langmuir model indicates that the adsorption energy was uniformly distributed throughout the entire adsorption surface, and there was no interaction and transmigration of adsorbate on the biosorbents surface after monolayer adsorption (Mittal et al. 2008). Higher values of $Q^{\circ}$ and lower values of $\mathrm{b}$ indicate that chemically treated biomass of Phanerochaete chrysosporium is a good sorbents for $\mathrm{Cr}(\mathrm{VI})$ adsorption.
Sorption kinetics study

Figure 2c represents the concentration variation profile of $\mathrm{Cr}(\mathrm{VI}), \mathrm{Cr}(\mathrm{III})$ and total chromium in the solution as a function of time, that is, kinetics of $\mathrm{Cr}(\mathrm{VI})$ biosorption on to FFB and CIFB at $\mathrm{pH} 2.0$, biomass dose $2.0 \mathrm{~g} \mathrm{~L}^{-1}$, initial metal concentration $100 \mathrm{mg} \mathrm{L}^{-1}$, temperature $40{ }^{\circ} \mathrm{C}$ and agitation speed of $100 \mathrm{rpm}$. The $\mathrm{Cr}$ (VI) depletes while $\mathrm{Cr}$ (III) concentration increases during the sorption process, and at the end, $\mathrm{Cr}$ (VI) concentration becomes undetectable for all forms of taken biomasses. These results further supported to the fact that during the removal process reduction $\mathrm{Cr}$ (VI) into $\mathrm{Cr}$ (III) followed by the sorption of chromium on the biomass surface takes place. Time concentration profile indicates the high kinetic rate which might be due to the excellent reducing power of the biomass. Similar type of kinetic rate was also reported earlier in some sea weed biomasses where sorption completed within 1-3 h (Sheng et al. 2004; Chen and Yang 2005). Acid treatment further reduces the equilibrium time which may be due to the enhanced reducing power of biomass as evident from Fig. 2a, b.

The kinetic constant and correlation coefficients for the pseudo-first-order and pseudo-second-order model were calculated from the plots of $\log \left(q_{\mathrm{e}}-q_{\mathrm{t}}\right)$ versus time for pseudofirst-order and $t / q_{\mathrm{t}}$ versus time for pseudo-second-order reaction kinetics (Fig. 3a), respectively. The values of different kinetic parameters are given in Table 3. Good correlation coefficients were observed for pseudo-second-order kinetic model as compare to pseudo-first-order model indicating that $\mathrm{Cr}$ (VI) uptake process can be explained with the pseudosecond-order kinetics model. This means that adsorption rate would be proportional to the metal ion concentration and the square of the number of free sites of the biosorbent, which corresponds to the term $\left(q_{\mathrm{e}}-q_{\mathrm{t}}\right)^{2}$ in the second-order model.

\section{Thermodynamic study}

The thermodynamic studies were performed for treated immobilized biomass at different temperatures (Fig. 2d), and Van't Hoff plot (Plot of $\ln \mathrm{Kc}$ vs. 1/T) was drown. Thermodynamic parameters were calculated using Van't Hoff plot and corresponding equations given in Table 1. Calculated values of thermodynamic parameters $(\Delta G$, $\Delta H$ and $\Delta S$ ) are given in Table 4 . The negative values of $\Delta G$ indicate that the sorption process was spontaneous in nature and increase in negative value of $\Delta G$ with increase in temperature indicates that raise in temperature favours the sorption process. Positive value of $\Delta H$ shows the endothermic nature of this sorption process, and positive value of $\Delta S$ represents that during sorption process, the degree of freedom of metal ions get increased, and it is due to the disorderliness of the adsorption at solid-liquid interface (Barkat et al. 2009). 

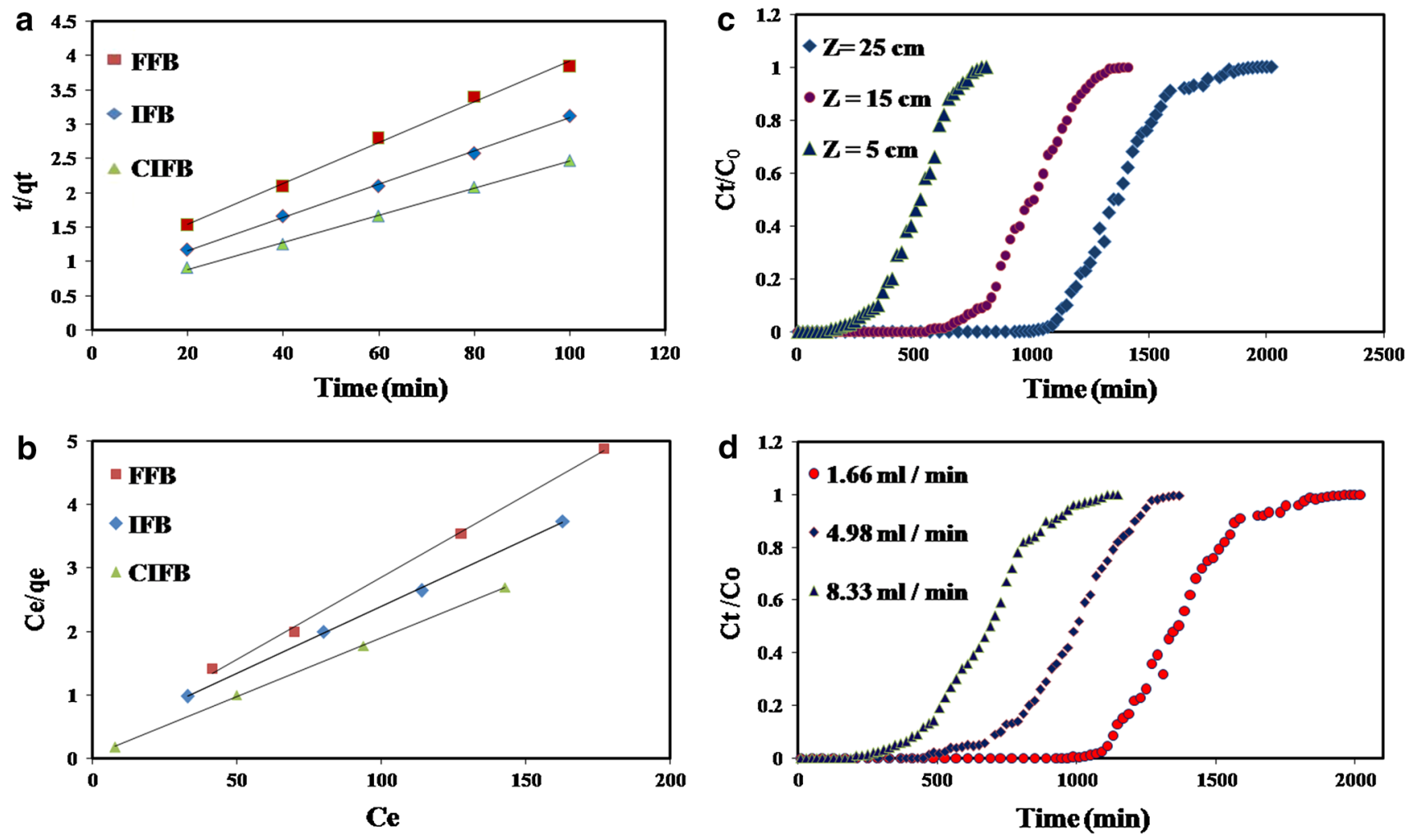

Fig. 3 a Pseudo-second-order plot for $\mathrm{Cr}(\mathrm{VI})$ removal. Conditions: $\mathrm{pH} 2.0$, initial metal concentration $100 \mathrm{mg} \mathrm{L}^{-1}$, biosorbent dose $2.0 \mathrm{~g} \mathrm{~L}^{-1}$, temperature $40{ }^{\circ} \mathrm{C}$. b Langmuir isotherm plot for $\mathrm{Cr}(\mathrm{VI})$ removal. Conditions: $\mathrm{pH} 2.0$, biosorbent dose $2.0 \mathrm{~g} \mathrm{~L}^{-1}$, temperature $40{ }^{\circ} \mathrm{C}$ at $100 \mathrm{rpm}$. c Breakthrough curves for $\mathrm{Cr}(\mathrm{VI})$ removal in

continuous up-flow fixed-bed bioreactor at different bed heights ( 5 , $15,25 \mathrm{~cm}$ ) and constant flow rate $1.66 \mathrm{~mL} \mathrm{~min}^{-1}$ and solution $\mathrm{pH}$ 2.0. d Breakthrough curves for the removal of $\mathrm{Cr}(\mathrm{VI})$ in continuous up-flow fixed-bed bioreactor of bed height $25 \mathrm{~cm}$ and different flow rates $\left(1.66,4.98\right.$ and $8.33 \mathrm{~mL} \mathrm{~min}^{-1}$ ) at $\mathrm{pH} 2.0$

Table 2 Langmuir and Freundlich isotherm model constants for biosorption of $\mathrm{Cr}(\mathrm{VI})$ on FFB, IFB and CIFB of P. chrysosporium

\begin{tabular}{|c|c|c|c|c|c|c|}
\hline \multirow[t]{2}{*}{ Biosorbent $P$. chrysosporium } & \multicolumn{3}{|c|}{ Langmuir constants } & \multicolumn{3}{|c|}{ Freundlich constants } \\
\hline & $Q^{\circ}\left(\mathrm{mg} \mathrm{g}^{-1}\right)$ & $b\left(\mathrm{~L} \mathrm{mg}^{-1}\right)$ & $R^{2}$ & $K_{\mathrm{F}}\left(\mathrm{mg} \mathrm{g}^{-1}\right)$ & $n$ & $R^{2}$ \\
\hline FFB & 38.46 & 0.095 & 0.999 & 13.51 & 5.20 & 0.878 \\
\hline IFB & 45.45 & 0.102 & 0.997 & 15.39 & 4.95 & 0.911 \\
\hline CIFB & 55.55 & 0.486 & 0.993 & 17.63 & 4.73 & 0.900 \\
\hline
\end{tabular}

FFB free fungal biomass, IFB immobilized fungal biomass, $C I F B$ chemically treated immobilized fungal biomass

Table 3 Kinetic parameters for the sorption of Cr(VI) on FFB, IFB and CIFB of $P$. chrysosporium

\begin{tabular}{|c|c|c|c|c|c|c|c|}
\hline \multirow[t]{2}{*}{ Type of Biomass } & \multicolumn{4}{|c|}{ Pseudo-first order } & \multicolumn{3}{|c|}{ Pseudo-second order } \\
\hline & $\mathrm{k}_{\mathrm{s}}\left(\mathrm{L} \min ^{-1}\right)$ & $\mathrm{q}_{\mathrm{e}}\left(\mathrm{mg} \mathrm{g}^{-1}\right)$ & $\mathrm{R}^{2}$ & $\mathrm{k}_{2}^{\prime}\left(\mathrm{g} \mathrm{mg}^{-1} \mathrm{~min}^{-1}\right)$ & $\mathrm{h}\left(\mathrm{mg} \mathrm{g}^{-1} \min ^{-1}\right)$ & $\mathrm{q}_{\mathrm{e}}\left(\mathrm{mg} \mathrm{g}^{-1}\right)$ & $\mathrm{R}^{2}$ \\
\hline FFB & 0.0229 & 28.57 & 0.913 & 0.00114 & 1.0482 & 30.20 & 0.995 \\
\hline IFB & 0.0207 & 32.73 & 0.858 & 0.00123 & 1.4742 & 34.48 & 0.998 \\
\hline CIFB & 0.0299 & 46.34 & 0.921 & 0.00904 & 2.0490 & 47.61 & 0.999 \\
\hline
\end{tabular}

$F F B$ free fungal biomass, $I F B$ immobilized fungal biomass, $C I F B$ chemically treated immobilized fungal biomass

Fixed-bed bioreactor studies for $\mathrm{Cr}(\mathrm{VI})$ removal

Removal of $\mathrm{Cr}(\mathrm{VI})$ in continuous up-flow fixed-bed bioreactor was studied at different flow rates $(1.66,4.98$ and $\left.8.33 \mathrm{~mL} \mathrm{~min}^{-1}\right)$ and different bed heights (5, 15 and $25 \mathrm{~cm}$ ). The effect of these two variables on the different parameters such as break through time $\left(t_{\mathrm{b}}\right)$, bed exhaustion time $\left(t_{\mathrm{e}}\right)$, volume treated up to break through point $\left(V_{\mathrm{b}}\right)$, 
volume treated up to exhaustion point $\left(V_{\mathrm{e}}\right)$, metal uptake capacity $\left(q \mathrm{mg} \mathrm{g}^{-1}\right)$, percentage removal of metal, empty bed contact time (EBCT) and sorbent usage rate (Ur, that is, weight of sorbent saturated per litre of solution treated) was determined. The results are shown in Table 5, which indicate that breakthrough time increase with increase in bed height and decrease with increase in flow rate. Maximum 1,610 and $3,120.8 \mathrm{~mL}$ volumes were treated by $25 \mathrm{~cm}$ bed height bioreactor at $1.66 \mathrm{~mL} \mathrm{~min}^{-1}$ flow rate, before breakthrough time $\left(t_{\mathrm{b}} 970 \mathrm{~min}\right)$ and exhaustion time $\left(t_{\mathrm{e}} 1,880 \mathrm{~min}\right)$, respectively. Figure $3 \mathrm{c}$, d represents the breakthrough curves $\left(C t / C_{0}\right.$ vs. time $)$ at different bed heights and at different flow rates. Maximum uptake capacity achieved was $68.87 \mathrm{mg} \mathrm{g}^{-1}$ for bed height $25 \mathrm{~cm}$ and at $1.66 \mathrm{~mL} \mathrm{~min}^{-1}$ flow rate. Regeneration of biomass or desorption was done by $10 \% \mathrm{NaOH}$ solution. Desorption of $25 \mathrm{~cm}$ bed height bioreactor at flow rate $4.98 \mathrm{~mL} \mathrm{m^{-1 }}$ was completed in $320 \mathrm{~min}$, with $98 \%$ elution efficiency. After desorption, $0.1 \mathrm{M} \mathrm{HCl}$ was passed through the bioreactor up to $1 \mathrm{~h}$ to reprotonate the surface groups followed by the washing through deionized water up to $1 \mathrm{~h}$.

\section{BDST model}

Bed depth service time plot, service time $(t)$ versus bed height $(Z)$ at different flow rates, is given in supplementary data S. Fig. 2. With the help of this plot, the bed sorption capacity $\left(N_{\mathrm{o}}\right)$ and sorption rate constant $\left(k_{\mathrm{a}}\right)$ were determined from the slope and intercept. Critical bed depth $\left(Z_{\mathrm{o}}\right)$ was calculated with the help of the equation in Table 1, given in theory section. Values of $N_{\mathrm{o}}, k_{\mathrm{a}}, Z_{\mathrm{o}}$ and $R^{2}$ are summarized in Table 6. The linear nature and high correlation coefficients of BDST plot indicate the validity of the BDST model for the present system. It has been found that the rate constant $(\mathrm{ka})$ decreased from 0.00456 to $0.000549 \mathrm{~L} /\left(\mathrm{mg} \mathrm{min}^{-1}\right)$ with increase of flow rate from 1.66 to $8.33 \mathrm{~mL} \mathrm{~min}{ }^{-1}$. For larger $\mathrm{k}_{\mathrm{a}}$, a short bed is required to avoid breakthrough, but as $\mathrm{k}_{\mathrm{a}}$ decreases, a progressively longer bed is required to avoid breakthrough for immediate effluent.

Table 5 Sorption data for up-flow fixed-bed bioreactor packed with immobilized acid-treated biomass containing luffa sponge discs (CIFB discs), for $\mathrm{Cr}(\mathrm{VI})$ sorption at different bed heights and
Table 4 Thermodynamic parameters for sorption of $\mathrm{Cr}(\mathrm{VI})$ on $\mathrm{HCl}$ pre-treated fungal biosorbent (CIFB) at different temperatures

\begin{tabular}{llll}
\hline $\begin{array}{l}\text { Temperature } \\
(\mathrm{K})\end{array}$ & $\begin{array}{l}-\Delta G \\
\left.(\mathrm{~kJ} \mathrm{~mol})^{-1}\right)\end{array}$ & $\begin{array}{l}\Delta H \\
\left.(\mathrm{~kJ} \mathrm{~mol})^{-1}\right)\end{array}$ & $\begin{array}{l}\Delta S \\
\left(\mathrm{~J} \mathrm{~mol}^{-1} \mathrm{~K}^{-1}\right)\end{array}$ \\
\hline 293 & 0.286 & 17.736 & 61.4 \\
303 & 0.8401 & & \\
313 & 1.5274 & & \\
\hline
\end{tabular}

Optimization of process using RSM

Two-level four-factor full-factorial CCD and two-level twofactor full-factorial CCD of RSM technique were applied for the optimization of batch $(\mathrm{pH}$, temperature, biomass dose and metal ion concentration) and continuous mode operation parameters (flow rate and bed height), respectively, for adsorption of $\mathrm{Cr}(\mathrm{VI})$ using software MINITAB ${ }^{\circledR}$ Release 15. Regression analysis was performed for both batch and continuous bioreactor study, and regression equations were obtained using the coefficients, which are given below:Regression equation for the batch mode operation:

$Y=25.2400-10.4667 \mathrm{pH}-20.3783$ biomass dose

+3.3300 metal concentration +4.4350 temperature

$+1.1892 \mathrm{pH} \times \mathrm{pH}+18.6292$ biomass dose

$\times$ biomass dose +0.2392 metal concentration

$\times$ metal concentration +0.3792 temperature

$\times$ temperature $+8.7100 \mathrm{pH} \times$ biomass dose

$-0.9250 \mathrm{pH} \times$ metal concentration $+1.9800 \mathrm{pH}$

$\times$ temperature +1.2100 biomass dose

$\times$ metal concentration -2.1350 biomass dose

$\times$ temperature +0.0300 metal concentration

$\times$ temperature.

where $Y$ is the response variable, predicted chromium uptake capacity $\left(\mathrm{mg} \mathrm{g}^{-1}\right)$. The values of standard deviation $R^{2}$ and $R^{2}$ (adjusted) were found to be-1.59144; 99.01 and $98.14 \%$, respectively.

Regression equation for the bioreactor study is as follows:

constant flow rate $\left(1.66 \mathrm{ml} \mathrm{min}^{-1}\right)$ and at different flow rates and constant bed height $25 \mathrm{~cm}$

\begin{tabular}{|c|c|c|c|c|c|c|c|c|c|c|}
\hline $\begin{array}{l}\text { Flow rate } \\
\left(\mathrm{mL} \min ^{-1}\right)\end{array}$ & $\begin{array}{l}\text { Bed height } \\
(\mathrm{cm})\end{array}$ & $\begin{array}{l}t_{\mathrm{b}} \\
(\min )\end{array}$ & $\begin{array}{l}t_{\mathrm{e}} \\
(\min )\end{array}$ & $\begin{array}{l}V_{\mathrm{b}} \\
(\mathrm{mL})\end{array}$ & $\begin{array}{l}V_{\mathrm{e}} \\
(\mathrm{mL})\end{array}$ & $\begin{array}{l}q \\
\left(\mathrm{mg} \mathrm{g}^{-1}\right)\end{array}$ & $M(\mathrm{gm})$ & $\begin{array}{l}\% \mathrm{Cr}(\mathrm{VI}) \\
\text { removal }\end{array}$ & $\begin{array}{l}\mathrm{EBCT} \\
(\mathrm{min})\end{array}$ & $\begin{array}{l}U_{\mathrm{r}} \\
\left(\mathrm{g} \mathrm{L}^{-1}\right)\end{array}$ \\
\hline 1.66 & 5 & 250 & 730 & 415 & $1,211.8$ & 41.76 & 0.87 & 30.00 & 9.45 & 2.096 \\
\hline 1.66 & 15 & 590 & 1,310 & 797.4 & $2,174.6$ & 52.1 & 2.47 & 59.17 & 28.37 & 2.521 \\
\hline 1.66 & 25 & 970 & 1,880 & 1,610 & $3,120.8$ & 68.87 & 4.36 & 96.21 & 47.28 & 2.708 \\
\hline 4.98 & 25 & 470 & 1,390 & $2,340.6$ & $6,922.2$ & 59.24 & 4.36 & 37.30 & 15.76 & 1.863 \\
\hline 8.33 & 25 & 230 & 1,010 & $2,665.6$ & $8,413.3$ & 51.76 & 4.36 & 26.82 & 9.42 & 1.636 \\
\hline
\end{tabular}


Table 6 BDST model parameters for the sorption of chromium (VI) in fixed-bed bioreactor

\begin{tabular}{lllll}
\hline $\left.\begin{array}{l}\text { Flow rate } \\
(\mathrm{mL} \mathrm{min}\end{array}{ }^{-1}\right)$ & $\begin{array}{l}N_{0} \\
\left(\mathrm{mg} \mathrm{L}^{-1}\right)\end{array}$ & $\begin{array}{l}k_{\mathrm{a}} \\
\left(\mathrm{L} \mathrm{mg}^{-1} \mathrm{~min}^{-1}\right)\end{array}$ & $\begin{array}{l}Z_{0} \\
(\mathrm{~cm})\end{array}$ & $R^{2}$ \\
\hline 1.66 & $3,914.6$ & 0.00456 & 0.225 & 0.998 \\
4.98 & $3,015.3$ & 0.00106 & 1.252 & 0.987 \\
8.33 & $2,380.5$ & 0.000549 & 5.819 & 0.992 \\
\hline
\end{tabular}

$Y=42.130-9.60$ flow rate +12.166 bed height

+1.672 flow rate $\times$ flow rate +6.622 bed height

$\times$ bed height -2.560 bed height $\times$ flow rate.

The values of $R^{2}$ and $R^{2}$ (adj.) were found to be 97.62 and $95.92 \%$, respectively.

\section{FTIR analysis}

FTIR analysis of biomass was done, before and after acid treatment and after $\mathrm{Cr}(\mathrm{VI})$ adsorption, in order to analyse the nature and groups present over the surface of biomass and groups involve in metal ions binding. Translucent sample discs were prepared by biomass pellets, and $\mathrm{KBr}$ in the ratio $1: 10$ and infrared spectra were obtained in the range of $4,000-400 \mathrm{~cm}^{-1}$, with the help of Perkin Elmer FTIR-1600 spectrophotometer, USA. FTIR spectra are shown in Fig. 4, which represents various absorption bands. The broad band around 3,200-3,400 $\mathrm{cm}^{-1}$ represents groups of the glucose and the stretching of the protein and the acetamido group of chitin fraction (Bai and Abraham 2002; Chhikara et al. 2010). Acid treatment sharpens the $-\mathrm{NH}$ stretching and polymeric association band $\left(3,200-3,400 \mathrm{~cm}^{-1}\right)$, which might be due to appearance of relatively pure amino sugars (D-glucosamines), resulting from partial hydrolysis of chitin (Bai and Abraham 2002; Nair and Madhavan 1992). A new peak appears at $2,300 \mathrm{~cm}^{-1}$ after acid treatment. This peak was due to $-\mathrm{NH}^{2+}$ and $-\mathrm{NH}^{3+}$ stretching vibration (Chhikara et al. 2010). Absorption peak at 2,924 and 2,856 $\mathrm{cm}^{-1}$ indicates the $-\mathrm{CH}$ stretching, and peak at $2,360 \mathrm{~cm}^{-1}$ is the assignment of $\mathrm{P}-\mathrm{H}$ groups. The absorption at $1,651 \mathrm{~cm}^{-1}$ can be attributed to the amide I band of amide bond in $\mathrm{N}$-acetyl glucosamine polymer or of the protein peptide bond (Bai and Abraham 2002). The peak at $1,550 \mathrm{~cm}^{-1}$ is the assignment of primary and secondary amines and amides ( $\mathrm{N}-\mathrm{H}$ bending). Peak at $1,371 \mathrm{~cm}^{-1}$ represents sulfamide bonds $(\mathrm{S}=\mathrm{O})$. Peaks at $1,035,1,080$ and $1,149 \mathrm{~cm}^{-1}$ assign to $-\mathrm{CN}$ stretching vibration of chitin-chitosan and protein fraction. Peeks ranging from 690 to $990 \mathrm{~cm}^{-1}$ represent $\mathrm{C}-\mathrm{H}$ bending. After $\mathrm{Cr}(\mathrm{VI})$ adsorption, decrease in the absorption intensity of $-\mathrm{NH}$ stretching $\left(3,388 \mathrm{~cm}^{-1}\right)$ and sifting the peak of $-\mathrm{NH}$ bending $\left(1,539-1,651 \mathrm{~cm}^{-1}\right)$ from $1,651.12$ to $1,643.41 \mathrm{~cm}^{-1}$ shows that of amino groups are involve in $\mathrm{Cr}(\mathrm{VI})$ binding. The major cell wall constituents like hexosamines and

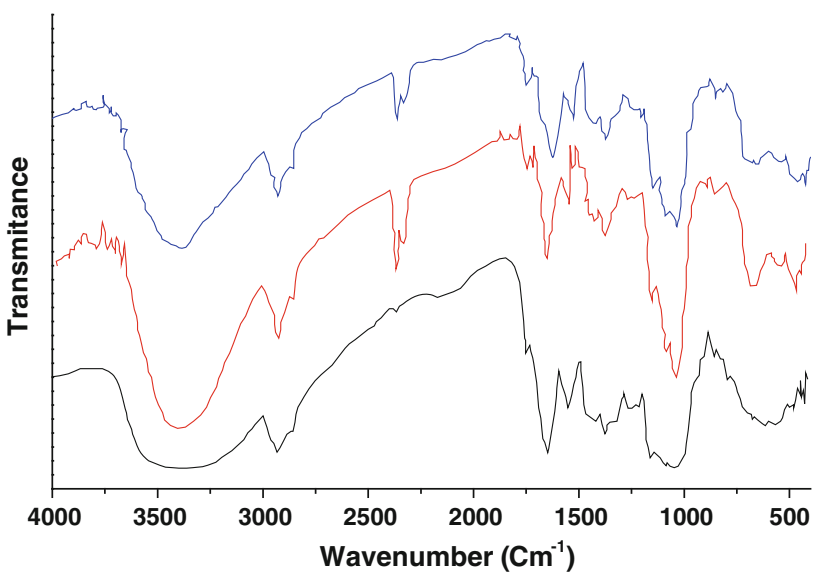

Fig. 4 FTIR spectra for P. chrysosporium before treatment (Lower, Black line), after $\mathrm{HCl}$ treatment (Middle, Red line) and after $\mathrm{Cr}(\mathrm{VI})$ adsorption over treated biomass (Upper, Blue line)

proteins are the providers of major portion of amino groups. These amino groups are protonated at the adsorption $\mathrm{pH}(\mathrm{pH}$ 2.0) and during acid treatment. Chromate ions which are negatively charged become electrostatically attracted towards the positively charged amines of the biomass cell wall (Bai and Abraham 2002), and these findings are in agreement with the results of many researchers (Gupta and Rastogi 2009).

\section{Conclusion}

Phanerochaete chrysosporium was successfully immobilized over luffa sponge and was used for removal of $\mathrm{Cr}(\mathrm{VI})$ from water. The immobilized biomass (IFB) showed better uptake capacity of $\mathrm{Cr}(\mathrm{VI})$ as compared to free fungal biomass (FFB) due to more surface area and less compactness. Acid treatment of the immobilized biomass showed increase in chromium uptake capacity of fungal biomass due to generation of relatively pure amino sugars as the result of acid hydrolysis followed by the protonation of the functional groups present on the surface of the biomass. During adsorption process, both the reduction of $\mathrm{Cr}(\mathrm{VI})$ into $\mathrm{Cr}(\mathrm{III})$ and its adsorption over biomass surface take place simultaneously. At optimum conditions, $92 \% \mathrm{Cr}(\mathrm{VI})$ was removed from the water, and remaining was reduced into lesser toxic form of chromium, that is, in $\mathrm{Cr}$ (III). FTIR analysis showed that amino groups ($\mathrm{NH}_{2}$ ) and hydroxyl groups are mainly involved in $\mathrm{Cr}(\mathrm{VI})$ adsorption. Thermodynamic studies indicate that the biosorption of $\mathrm{Cr}(\mathrm{VI})$ was endothermic and spontaneous process. Various parameters such as temperature, $\mathrm{pH}$, biomass dose and $\mathrm{Cr}(\mathrm{VI})$ concentration in solution govern the biosorption of $\mathrm{Cr}(\mathrm{VI})$ over the immobilized fungal biomass on luffa sponge in batch mode operation. In batch studies, the maximum uptake capacity of $P$. chrysosporium biomass $\left(46.5 \mathrm{mg} \mathrm{g}^{-1}\right)$ was achieved at $\mathrm{pH} 2.0$; biomass dose $2.0 \mathrm{~g} \mathrm{~L}^{-1}$; metal ion concentration $100 \mathrm{mg} \mathrm{L}^{-1}$ and temperature $40^{\circ} \mathrm{C}$. The flow 
rate and bed height are main influencing factors for the adsorption process in continuous up-flow fixed-bed bioreactor. In continuous up-flow mode of operation, the maximum uptake capacity $\left(68.87 \mathrm{mg} \mathrm{g}^{-1}\right)$ was achieved at bed height $25 \mathrm{~cm}$ and flow rate $1.66 \mathrm{~mL} \mathrm{~min}^{-1}$. Under the above-mentioned conditions, the treated volume up to breakthrough time $\left(t_{\mathrm{b}} 970\right.$ min.) and treated volume up to bed exhaustion time $\left(t_{\mathrm{e}}\right.$ $1,880 \mathrm{~min}$.) were $1,610,3,120.80 \mathrm{~mL}$, respectively. Overall, $P$. chrysosporium was immobilized over luffa sponge and its acid treatment improved the uptake capacity of biomass. This immobilized and acid-treated biomass system can be used very efficiently for the removal of $\mathrm{Cr}(\mathrm{VI})$ from the water.

Acknowledgments This work was financially supported by fellowship grant provided by MHRD. The authors are also thankful for technical assistance of School of Biochemical Engineering and Department of Applied Chemistry, Indian Institute of Technology (BHU) Varanasi. Special thanks to, Mr. Reet Ram Verma, a farmer for providing luffa sponge.

\section{Nomenclature}

$A_{\mathrm{c}}$

$b$

$C_{\mathrm{Ae}}$

$C_{\mathrm{b}}$

$C_{\mathrm{e}}$

$C_{\mathrm{i}}$

$C_{\mathrm{t}}$

$C_{0}$

E

$\Delta G$

h

$\Delta H$

$k_{\mathrm{a}}$

$K_{\mathrm{c}}$

$K_{\mathrm{F}}$

$k_{\mathrm{s}}$

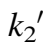

M

$m_{\mathrm{d}}$

$n$
$N_{\mathrm{b}}$

$N_{\mathrm{o}}$

$Q$

$Q^{\mathrm{o}}$

$q_{\mathrm{e}}$

$q_{\mathrm{t}}$

$q_{\text {tot }}$

$R$

$\Delta S$

$t$

$t_{\mathrm{b}}$

$t_{\mathrm{e}}$

$u$

$U_{\mathrm{r}}$

V

$V_{\mathrm{b}}$

Breakthrough concentration of metal ions $\left(\mathrm{mg} \mathrm{L}^{-1}\right)$

Equilibrium concentration of solute in solution $\left(\mathrm{mg} \mathrm{L}^{-1}\right)$

Initial metal ion concentration in solution $\left(\mathrm{mg} \mathrm{L}^{-1}\right)$

Remaining metal ion concentration in solution at any time $\left(\mathrm{mg} \mathrm{L}^{-1}\right)$

Metal ion concentration in the inlet solution $\left(\mathrm{mg} \mathrm{L}^{-1}\right)$

Elution efficiency

Gibbs free energy change

(kcal mol ${ }^{-1}$ )

Initial sorption rate $\left(\mathrm{mg} \mathrm{g}^{-1} \mathrm{~min}^{-1}\right)$

Enthalpy change $\left(\mathrm{kcal} \mathrm{mol}^{-1}\right)$

Rate constant in BDST model

$\left(\mathrm{L} \mathrm{mg}{ }^{-1} \min ^{-1}\right.$ )

Equilibrium constant

Freundlich constant indicative of sorption (uptake) capacity $\left(\mathrm{mg} \mathrm{g}^{-1}\right.$ )

Equilibrium rate constant of pseudofirst-order sorption $\left(\mathrm{min}^{-1}\right)$

Equilibrium rate constant

$\left(\mathrm{g} \mathrm{mg}^{-1} \mathrm{~min}^{-1}\right.$ )

Weight of biosorbent in bioreactor (gm)

Metal mass desorbed

Freundlich constant indicates the intensity of sorption
Bed volumes treated up to breakthrough

Sorption or uptake capacity of bed $\left(\mathrm{mg} \mathrm{L}^{-1}\right)$

Volumetric flow rate of solution $\left(\mathrm{mL} \min ^{-1}\right)$

Sorption capacity of biosorbent under experimental conditions $\left(\mathrm{mg} \mathrm{g}^{-1}\right)$

Uptake capacity of sorbent at equilibrium $\left(\mathrm{mg} \mathrm{g}^{-1}\right.$ )

Uptake capacity of sorbent at any time $\left(\mathrm{mg} \mathrm{g}^{-1}\right)$

Total quantity of metal adsorbed in the bioreactor

Universal gas constant

$(8.314 \mathrm{~J} /(\mathrm{mol} \mathrm{K}))$

Change in the entropy $\left(\mathrm{cal} \mathrm{mol}^{-1} \mathrm{~K}^{-1}\right.$ )

Time

Breakthrough (min)

Bed exhaustion time (min)

Linear velocity of solution in

bioreactor $\left(\mathrm{cm} \mathrm{min}^{-1}\right)$

Sorbent usage rate $\left(\mathrm{g} \mathrm{L}^{-1}\right)$

Volume of solution (L)

Volume of the effluent treated up to breakthrough time $(\mathrm{mL})$

Sorbent volume in the bed $(\mathrm{mL})$

Volume of the effluent treated up to exhaustion time $(\mathrm{mL})$

Volume of effluent $(\mathrm{mL})$

Weight of biosorbent $(\mathrm{g})$

The total amount of metal ion fed to the bioreactor $(\mathrm{mg})$

Bed height $(\mathrm{cm})$

Critical bed height $(\mathrm{cm})$

Sorbent density in the bioreactor $\left(\mathrm{g} \mathrm{cm}^{-3}\right)$

CCD

MEA

FFB

Central composite design

Malt extract agar

Free fungal biomass

IFB Immobilized fungal biomass

(untreated)

CIFB Chemically treated biomass (acid treated)

\section{References}

Bai RS, Abraham TE (2002) studies on enhancement of $\mathrm{Cr}(\mathrm{VI})$ biosorption by chemically modified biomass of Rhizopus nigricans. Water Res 36:1224-1236

Barkat M, Nibou D, Chegrouche S, Mellah A (2009) A Kinetics and thermodynamics studies of chromium (VI) ions adsorption onto activated carbon from aqueous solutions. Chem Eng Process 48:38-47 
Bohart GS, Adams EQ (1920) Some aspects of the behavior of charcoal with respect to chlorine. J Am Chem Soc 42:523-544

Chen JP, Yang L (2005) Chemical modification of sargassum sp. for prevention of organic leaching and enhancement of uptake during metal biosorption. Ind Eng Chem Res 44:9931-9942

Chhikara S, Hooda A, Rana L, Dhankhar R (2010) Chromium (VI) biosorption by immobilized Aspergillus niger in continuous flow system with special reference to FTIR analysis. J Environ Biol 31(5):561-566

Demirbas E, Kobya M, Senturk E, Ozkan T (2004) Adsorption kinetics for the removal of chromium (VI) from aqueous solutions on the activated carbons prepared from agricultural wastes. Water S A 30:533-540

Erdem M, Ozverdi A (2006) Kinetics and thermodynamics of Cd(II) adsorption onto pyrite and synthetic iron sulphide. Sep Purif Technol 51:240-246

Fourest E, Volesky B (1997) Alginate properties and heavy metal biosorption by marine algae. Biochem Biotechnol 67:215-226

Freundlich H (1907) Ueber die adsorption in loesungen. Z Phys Chem $57: 385-470$

Gupta VK, Rastogi A (2009) Biosorption of hexavalent chromium by raw and acid-treated green alga Oedogonium hatei from aqueous solutions. J Hazard Mater 163:396-402

Gupta VK, Srivastava SK, Mohan D, Sharma S (1997) Design parameters for fixed bed reactors of activated carbon developed from fertilizer waste for the removal of some heavy metal ions. Waste Manage 17(8):517-522

Gupta VK, Shrivastava AK, Jain N (2001) Biosorption of chromium(VI) from aqueous solutions by green algae Spirogyra species. Water Res 35:4079-4085

Gupta VK, Ali I, Saini VK (2007) Defluoridation of wastewaters using waste carbon slurry. Water Res 41:3307-3316

Gupta VK, Rastogi A, Nayak A (2010) Biosorption of nickel onto treated alga (Oedogonium hatei): application of isotherm and kinetic models. J Colloid Interf Sci 342:533-539

Gupta VK, Agarwal S, Saleh TA (2011a) Chromium removal by combining the magnetic properties of iron oxide with adsorption properties of carbon nanotubes. Water Res 45:2207-2212

Gupta VK, Agarwal S, Saleh TA (2011b) Synthesis and characterization of alumina-coated carbon nanotubes and their application for lead removal. J Hazard Mater 185:17-23

Gupta VK, Gupta B, Rastogi A, Agarwal S, Nayak A (2011c) A comparative investigation on adsorption performances of mesoporous activated carbon prepared from waste rubber tire and activated carbon for a hazardous azo dye-acid blue 113 . J Hazard Mater 186:891-901

Hasan SH, Singh KK, Prakash O, Talat M, Ho YS (2008) Removal of $\mathrm{Cr}(\mathrm{VI})$ from aqueous solutions using agricultural waste 'maize bran'. J Hazard Mater 152(1):356-365

Ho YS (2006) Second-order kinetic model for the sorption of cadmium onto tree fern: a comparison of linear and non-linear methods. Water Res 40:119-125

Ho YS, McKay G (1999) Comparative sorption kinetic studies of dye and aromatic compounds onto fly ash. J Environ Sci Health 34:1179-1204

Hutchins RA (1973) New simplified design of activated carbon systems. Am J Chem 80:133-138

Iqbal M, Edyvean RGJ (2005) Luffa sponge immobilized fungal biosorbent: a robust system for cadmium and other dissolved metal removal from aqueous solution. Chemosphere 61:510-518

Iqbal M, Saeed A, Edyvean RGJ, O'Sullivan B, Styring P (2005) Production of fungal biomass immobilized luffa sponge (FBILS)discs for the removal of heavy metal ions and chlorinated compounds from aqueous solution. Biotechnol Lett 27:1319-1323

Kacar Y, Arpa C, Tan S, Denizil A, Genc O, Arica MY (2002) Biosorption of $\mathrm{Hg}$ (II) and $\mathrm{Cd}(\mathrm{II})$ from aqueous solution: comparison of biosorptive capacity of alginate and immobilized live and heat inactivated Phanerochaete chrysosporium. Process Biochem 37:601-610

Kiran I, Akar T, Ozcan AS, Ozcan A, Tunali S (2006) Biosorption kinetics and isotherm studies of acid red 57 by dried Cephalosporium aphidicola cells from aqueous solutions. Biochem Eng J 31:197-203

Kobya M (2004) Adsorption, kinetic and equilibrium studies of $\mathrm{Cr}(\mathrm{VI})$ by hazelnut shell activated carbon. Adsorp Sci Technol 22:51-64

Langmuir I (1918) The adsorption of gases on plane surfaces of glass, mica and platinum. J Am Chem Soc 40:1361-1403

Liu Y, Liu YJ (2008) Biosorption isotherms, kinetics and thermodynamics. Sep Purif Technol 61:229-242

Mittal A, Gupta VK, Malviya A, Mittal J (2008) Process development for the batch and bulk removal and recovery of a hazardous, watersoluble azo dye (metanil yellow) by adsorption over waste materials (bottom ash and de-oiled soya). J Hazard Mater 151:821-832

Mittal A, Kaur D, Malviya A, Mittal J, Gupta VK (2009a) Adsorption studies on the removal of coloring agent phenol red from wastewater using waste materials as adsorbents. J Colloid Interf Sci 337:345-354

Mittal A, Mittal J, Malviya A, Gupta VK (2009b) Adsorptive removal of hazardous anionic dye "congo red" from wastewater using waste materials and recovery by desorption. J Colloid Interf Sci 340:16-26

Mittal A, Mittal J, Malviya A, Gupta VK (2010a) Removal and recovery of Chrysoidine $\mathrm{Y}$ from aqueous solutions by waste materials. J Colloid Interf Sci 344:497-507

Mittal A, Mittal J, Malviya A, Kaur D, Gupta VK (2010b) Decoloration treatment of a hazardous triarylmethane dye, light green SF (yellowish) by waste material adsorbents. J Colloid Interf Sci 342:518-527

Mittal A, Mittal J, Malviya A, Kaur D, Gupta VK (2010c) Adsorption of hazardous dye crystal violet from wastewater by waste materials. J Colloid Interf Sci 343:463-473

Murugesan GS, Sathishkumar M, Swaminathan K (2006) Arsenic removal from groundwater by pretreated waste tea fungal biomass. Bioresour Technol 97:483-487

Nair RKG, Madhavan P (1992) Chitin, chitosan and their derivatives, production and applications. In: Proceeding VIII carbohydrate conference 18-20 Nov Trivandrum, pp 59-65

Nouri L, Ghodbane I, Hamdaoui O, Chiha M (2007) Batch sorption dynamics and equilibrium for the removal of cadmium ions from aqueous phase using wheat bran. J Hazard Mater 149:115-125

Park D, Yun YS, Park JM (2005) Studies on hexavalent chromium biosorption by chemically-treated biomass of Ecklonia sp. Chemosphere 60:1356-1364

Perez RR, Benito GG, Miranda MP (1997) Chlorophenol degradation by Phanerochaete chrysosporium. Bioresour Technol 60:207-213

Pokhrel D, Viraraghavan T (2007) Arsenic removal from an aqueous solution by modified A. niger biomass: batch kinetic and isotherm studies. J Hazard Mater 15:818-825

Reddy GVB, Gelpke MDS, Gold MH (1998) Degradation of 2,4,6trichlorophenol by Phanerochaete chrysosporium: involvement of reductive dechlorination. J Bacteriol 180:5159-5164

Sheng PX, Ting YP, Chen JP, Hong L (2004) Sorption of lead, copper, cadmium, zinc, and nickel by marine algal biomass: characterization of biosorptive capacity and investigation of mechanisms. J Colloid Interface Sci 275(1):131-141

Singh KK, Rastogi R, Hasan SH (2005) Removal of Cr(VI) from waste water using rice bran. J Colloid Interf Sci 290:61-68

Tan IAW, Ahmad AL, Hameed BH (2008) Optimization of preparation conditions for activated carbons from coconut husk using response surface methodology. Chem Eng J 137(3):462-470

Vijayaraghavan K, Jegan J, Palanivelu K, Velan M (2005) Batch and column removal of copper from aqueous solution using a brown marine alga Turbinaria ornate. Chem Eng J 106:177-184

Yang L, Chen P (2008) biosorption of hexavalent chromium onto raw and chemically modified Sargassum sp. Bioresour Technol 99:297-307 